\title{
A Comparative Evaluation of the Use of Artificial Neural Networks for Modeling the Rainfall-Runoff Relationship in Water Resources Management
}

\author{
Evren Turhan ${ }^{1}$ \\ 1 Department of Civil Engineering, Adana Alparslan Türkeş Science and Technology University, Turkey \\ E-mail: eturhan@atu.edu.tr
}

\begin{abstract}
Recently, Artificial Neural Network (ANN) methods, which have been successfully applied in many fields, have been considered for a large number of reliable streamflow estimation and modeling studies for the design and project planning of hydraulic structures. The present study aimed to model the rainfall-runoff relationship using different ANN methods. The Nergizlik Dam, located in the Seyhan sub-basin and one of the important basins in Turkey, was chosen as the study area. Analyses were carried out based on streamflow estimation with the help of observed precipitation and runoff data at certain time intervals. Feed Forward Backpropagation Neural Network (FFBPNN) and Generalized Regression Neural Network (GRNN) methods were adopted, and obtained results were compared with Multiple Linear Regression (MLR) method, which is accepted as the traditional method. Also, the models were performed using three different transfer functions to create optimum ANN modeling. As a result of the study, it was seen that ANN methods showed statistically good results in rainfall-runoff modeling, and the developed models can be successfully applied in the estimation of average monthly flows.
\end{abstract}

Keywords: rainfall-runoff modeling, artificial neural networks methods, MLR, Nergizlik Dam

\section{INTRODUCTION}

Rapid population growth and adverse environmental conditions make it necessary to conduct good planning in terms of the protection and use of water, which is a limited resource (Aktürk and Y1ldiz, 2018; Tayyab et al., 2019, Obasi et al., 2020; Ali and Shahbaz, 2020). Globally, problems have increased with the effects of climate change, and it is predicted that the decrease in usable water resources will create a serious risk every year (Selek et al., 2019). One of the most valid ways to reduce the risk is to carry out accurate planning. The available flow data should be sufficient for planning. Creating prediction models with flow data in basins where water resources are gathered is considered very valuable in terms of hydrology (Riad et al., 2004; Huo et al., 2012; Nourani et al., 2015; Komasi and Sharghi, 2016; Sun et al., 2019; LV et al., 2020; Adnan et al., 2020). The fact that hydrological information acquisition processes - including flow data - are mostly nonlinear, making calculations and modeling quite difficult (Gümüş and Kavşut, 2013; Patel et al., 2016; Patel and Joshi, 2017; Kumar et al., 2019). Therefore, it is thought that using ANN, which is a closed-box model, can greatly facilitate solutions as prediction model using observed rainfall and runoff data (Kişi, 2008; Okkan et al., 2018).

In the literature, there are various studies in which ANN methods have been used in rainfallrunoff modeling. In these studies, in general, the observed rainfall and runoff data have been evaluated as input values, and forecasting with the help of the flow data was constituted to predict the output value (Gümüş et al., 2013; Farajzadeh et al., 2014; Nourani et al., 2015; Nawaz et al., 2015; Aichouri et al., 2015; Hosseini and Mahjouri, 2016; Komasi and Sharghi, 2016; Turhan et al., 2016a; Turhan et al., 2016b; Patel and Joshi, 2017; Singh et al., 2018; Tayyab et al., 2019; Asadi et al., 2019; Üneş et al., 2019; Turhan et al., 
2019; Vidyarthi et al., 2020; LV et al., 2020). The studies, in which inputs were selected as rainfall, temperature, past flow rate values in terms of various hydrological data and in which runoff prediction models were selected as methodology, are also included in the literature (Besaw et al., 2010; Panagoulia et al., 2017; Ateeq-ur-Rauf et al. 2018; Adnan et al., 2020; Boucher et al., 2020). It is possible to come across many studies adopting FFBPNN, GRNN, and Radial Based Function Network (RBFN) methods (Alp and Cığızoğlu, 2004; Kişi, 2008; Ustaoğlu et al., 2008; Besaw et al., 2010; Okkan and Dalkılıç, 2012; Gümüş and Kavşut, 2013; Tayyab et al. 2016; Sonmez et al., 2016; Yin et al., 2016; Yaseen et al., 2016; Zhou et al., 2018; Modaresi et al., 2018; Tayfur et al., 2018). Also, to test the sensitivity of ANN methods, comparisons were made with the results of MLR and Multiple Nonlinear Regression (MNLR) techniques, which are widely accepted methods (Ustaoğlu et al., 2008; Eyüpoğlu et al., 2010; Gümüş et al., 2013; Ramana, 2014; Patel et al., 2016; Ilaboya and Igbinedion, 2019; Sun et al., 2019; Song et al., 2020). As a result of the studies, it was observed that ANN methods yielded satisfactory results compared to traditional analyses (Gümüş et al., 2013; Meng et al., 2015; Turhan et al., 2016a; Daliakopoulos and Tsanis, 2016; Shoaib et al., 2018; Ali and Shahbaz, 2020). Many water resource areas such as basins, dams and rivers are preferred as study areas in applications where ANN methods are tested for modeling the rainfall-runoff relationship (Dorum et al., 2010; Huo et al., 2012; Farajzadeh et al., 2014; Nourani et al., 2015; Tayyab et al. 2016; Mishra and Karmakar, 2018; Obasi et al., 2020; LV et al., 2020). Besides, in order to investigate the optimum ANN model, there are some sensitivity analysis studies in which transfer functions, hidden neurons or several variables (the number of spreads etc.) have been tested (Kişi, 2008; Yonaba et al., 2010; Nacar et al., 2017; Yüksek et al., 2018; Sahoo et al., 2019; Sun et al., 2019; Ilaboya and Igbinedion, 2019; Drisya et al., 2020).

The present study investigated the modeling of the rainfall-runoff relationship, which is considered to be an important factor in the development of hydraulic structures. The Nergizlik Dam area in the Seyhan sub-basin, which includes fertile agricultural lands, was chosen as the study area. Observed rainfall and flow or streamflow data were regarded as input values, and the output was evaluated as streamflow data. Different ANN methods, such as Feed Forward Back Propagation Neural Networks (FFBPNN) and Generalized Regression Neural Networks (GRNN) were applied, and obtained results were compared with the Multiple Linear Regression (MLR) as a conventional method. In addition, in order to create optimum ANN modeling, three different transfer functions were investigated as Logarithmic sigmoid, Hyperbolic tangent sigmoid and Purelin (linear), different numbers of hidden neurons and the number of spread variables were examined to observe the effects on the models. Therefore, in this study, it is aimed to create an effective prediction model in solving a complex problem such as rainfall-runoff modeling. The applicability of artificial intelligence methods has been investigated in order to take preventive measures and to manage water resources properly in drainage basins such as dams, which are most affected by global climate change. Analyzing the model sensitivities of different variables for each ANN method, the obtained results will make positive contributions to the literature in terms of optimum ANN model.

\section{MATERIALS AND METHODS}

\section{Study area}

The Nergizlik Dam, which is located in the western part of Turkey and extending northwards from the Çukurova region, was built on the Üçürge Stream and approximately $50 \mathrm{~km}$ far from Adana in 1995 (Fig. 1). The dam meets the agricultural irrigation needs of 2300 hectare area and it can be used for flood prevention. The volume of this earth-fill type dam is approximately $14.74 \times 10^{6} \mathrm{~m}^{3}$; its height from the riverbed is $70 \mathrm{~m}$, the lake volume at normal water elevation is $21.80 \mathrm{hm}^{3}$ and the lake area at normal water level is $1.08 \mathrm{~km}^{2}$ (Turkish State Hydraulic Works (known locally as DSI), 2011). In the Seyhan sub-basin, where the Nergizlik Dam is located, the Mediterranean and continental climates are dominant. Due to the climate characteristics, in the Mediterranean climate region, the winter season is generally rainy, although the snowfall is observed where the continental climate region is effective.

Seyhan basin is one of the basins that will be significantly affected by drought due to climate change. As a result of some studies, monthly average temperatures will increase up to $30^{\circ} \mathrm{C}$ in the 


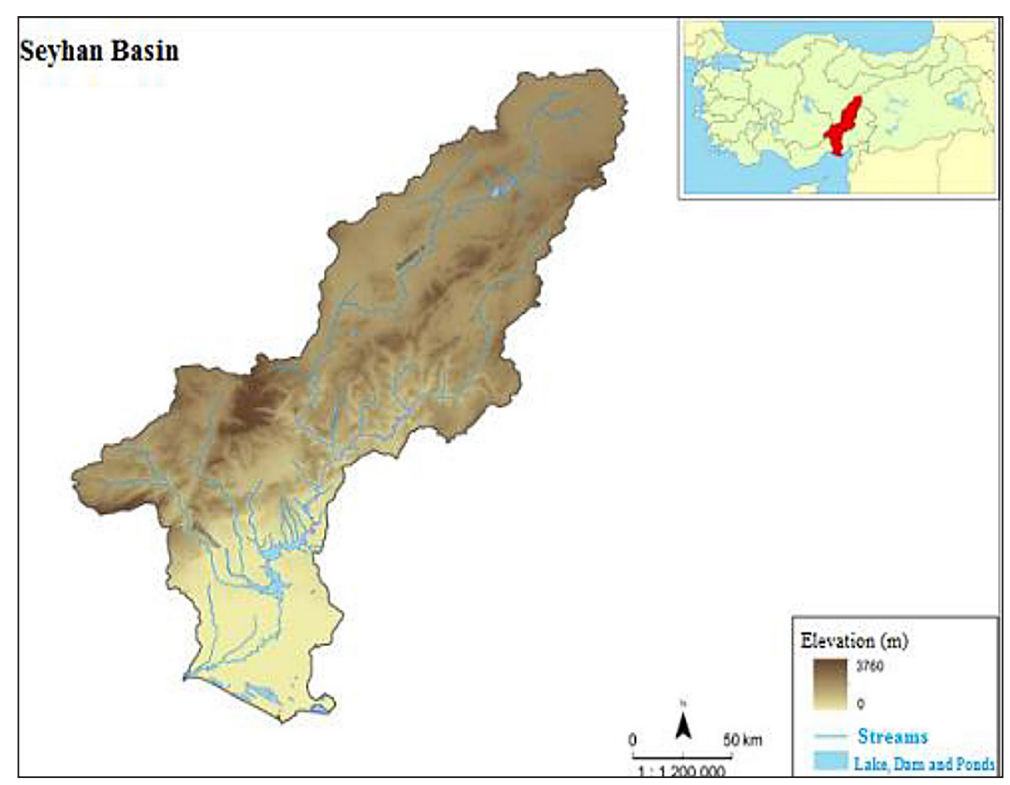

Fig. 1. Physical map of the Seyhan Basin (Turhan, 2012)

Seyhan Basin; it has been determined that there will be a $25 \%$ decrease in the annual precipitation amount. Thus, it has been predicted that there will be a $14 \%$ increase in the potential evapotranspiration and a $17 \%$ decrease in actual evapotranspiration, depending on the decrease in the precipitation. Significant reduction of up to $30 \%$ will occur in surface water resources, snow storage and groundwater potential. It is predicted that this climate change will cause a decrease in the water resources of the Seyhan Basin (Özfidaner et al. 2018; Gümüş, 2019).

In the study, the rainfall data from Karaisalı and Çatalan, which are the closest two rainfall observation stations (ROS) to the Nergizlik Dam site, were evaluated between 1992 and 2011. The data from this period were obtained from the DSI and Turkish State Meteorology Works (known locally as DMI). The average monthly flow values obtained from Flow Observation Stations (FOS) and the average monthly rainfall values from ROS were used. As can be seen in Table 1, the data from FOS nos 1820 and 1828 (Körkün Suyu- Hacılıköprüsü and Çakıt Suyu- Salbaş) and Ros nos 17351 and 17936 (Karaisalı and Çatalan) were utilized and also the location of the stations can be seen in Figure 2 (Electrical Work Surveying Administration (EWSA), 2008 and DSI, 2011).

In order to observe the relationship between two or more variables and to determine the effect of the relationship, regression-correlation analysis can be performed (Gümüş et al., 2013; Bakış and Göncü, 2015; Akçakoca and Apaydın, 2020). It was observed that the hydrological relationship between the specified FOSs and ROSs was quite robust, since the coefficient was found close to the value of "1" as a result of the correlation made using the MS-Excel program. The observed monthly average flow values are represented as $Q_{t}$, rainfall values as $P_{t}$, delayed streamflow values before and after $t$ as $Q_{t-1}$ and $Q_{t+1}$, respectively, and the rainfall values before and after $t$ as $P_{t-1}$ and $P_{t+1}$, respectively. Various artificial neural network architectures were used to model rainfall and runoff data at specific times, and the obtained results of streamflow estimations were compared.

Table 1. FOS and ROS data (EWSA, 2008 and DSI, 2011)

\begin{tabular}{|c|c|c|c|c|c|c|}
\hline FOS and ROS No. & Station Name & Location & Latitude $(\mathrm{N})$ & Longitude (E) & Altitude $(\mathrm{m})$ & Time Period \\
\hline 1820 & $\begin{array}{c}\text { Körkün Suyu- } \\
\text { Hacılıköprüsü FOS }\end{array}$ & \multirow{4}{*}{ Karaisalı } & $37^{\circ} 17^{\prime} 44^{\prime \prime}$ & $35^{\circ} 09^{\prime} 17^{\prime \prime}$ & 167.00 & \multirow{4}{*}{ 1992-2011 } \\
\hline 1828 & $\begin{array}{c}\text { Çakıt Suyu- Salbaş } \\
\text { FOS }\end{array}$ & & $37^{\circ} 06^{\prime} 14^{\prime \prime}$ & $35^{\circ} 06^{\prime} 26^{\prime \prime}$ & 80.00 & \\
\hline 17936 & Karaisalı ROS & & $37^{\circ} 15^{\prime} 05^{\prime \prime}$ & $35^{\circ} 03^{\prime} 47^{\prime \prime}$ & 241.00 & \\
\hline 17351 & Çatalan ROS & & $37^{\circ} 13^{\prime} 00^{\prime \prime}$ & $35^{\circ} 17^{\prime} 00^{\prime \prime}$ & 65.00 & \\
\hline
\end{tabular}




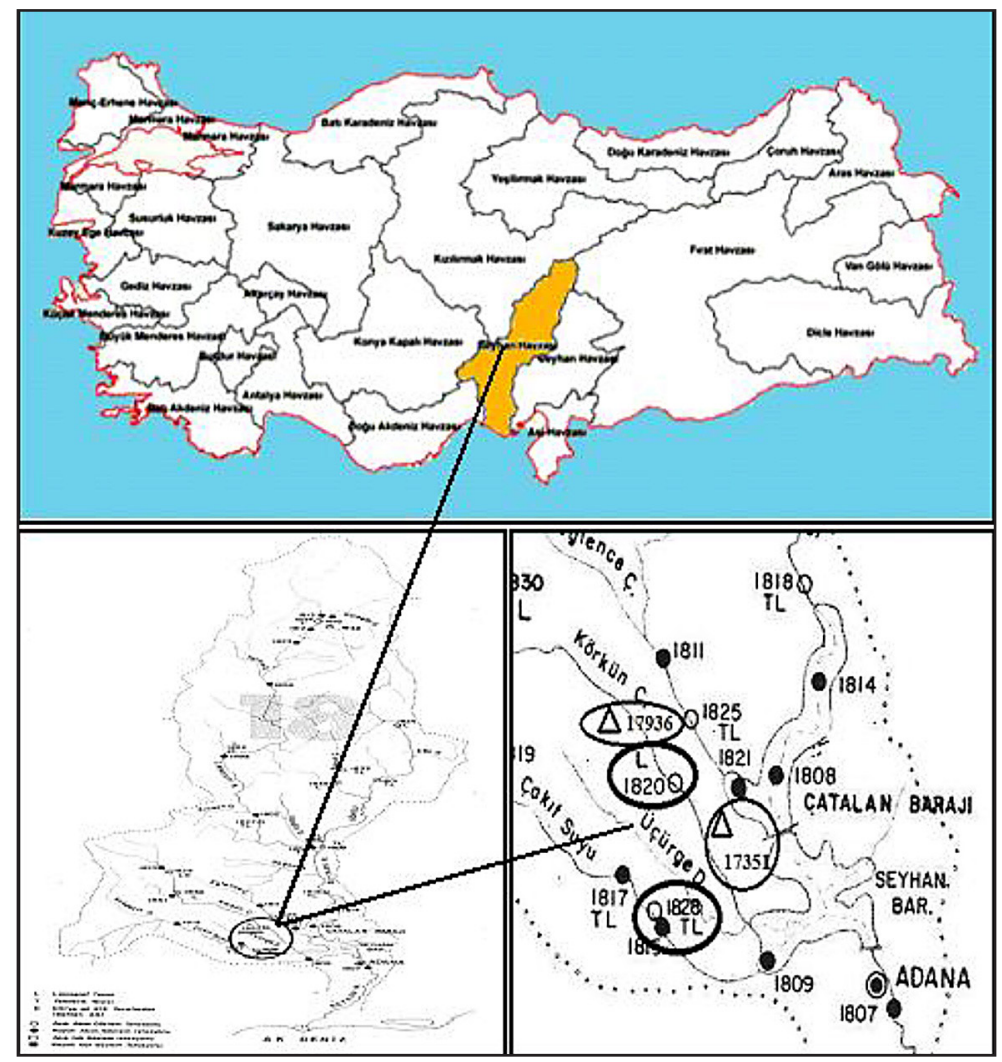

Fig. 2. Seyhan sub-basin map and FOSs and ROSs used in modeling

\section{Artificial Neural Networks (ANN)}

ANN models are computer applications that perform learning, association, classification, generalization, and optimization processes based on available data (Sattari et al., 2007; Okkan and Mollamahmutoğlu, 2010). To create these models, many methods such as FFBPNN, GRNN, RBFN etc. can be used (Gümüş and Kavşut, 2013; Gümüş et al., 2018). The general characteristic of all methods is that they contain input, hidden and output layers (Ustaoğlu et al., 2008).

There is no limit to the number of hidden or intermediate layers and the outputs of neurons in one layer can be presented to the next layer as input values employing weights. In the input layer, a weight coefficient is applied to obtained information with the help of the input vector; from here it is transmitted to the neurons in the hidden layer (Gümüş et al., 2018; Üneş et al., 2019). Afterwards, the output of the network is completed as a result of applying different processes to the information in the hidden and output layers (Fig. 3). This means that the architectural structure is a non-linear feature in Feed Forward Network models. A backpropagation algorithm is a programming language that enables a continuous function to be formed with the desired convergence, provided that there are a sufficient number of neurons in the hidden layer (Sattari et al., 2007; Sattari et al., 2011; Ghumman et al., 2011; Aktürk and Y1ldız, 2015; Meng et al., 2015; Tayyab et al., 2016; Nacar et al., 2017; Bisoyi et al., 2019; Ali and Shahbaz, 2020; Song et al., 2020).

It is essential to determine the weight values for the neural network for the FFBPNN. With a net function found as the sum of the weighted input values, the effects of the input data on this neuron are stated. These inputs are transferred to the output layer with the help of functions called transfer or activation functions (Yildiran and Kandemir, 2018). In this study, three different

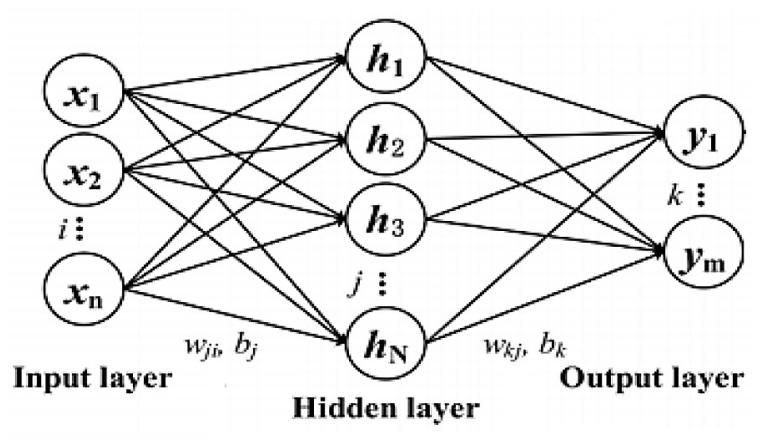

Fig. 3. A general structure of ANN 
transfer functions, which are Logsig, Tansig and Purelin (Linear), are tested.

GRNN is evaluated as a Feed Forward ANN model consisting of four layers: input, pattern, summation and output (Gümüş et al., 2013; Yin et al., 2016; Tayyab et al., 2016; Modaresi et al., 2018; Oral et al., 2018; Tayfur et al., 2018). The difference of the GRNN from the FFBPNN is that they do not require a training process to be repeated over and over (Seçkin et al., 2013). The general schematic structures of the FFBPNN and GRNN are shown in Figure 4 and Figure 5 as can be seen below.

Levenberg-Marquardt algorithm - which is accepted as an advanced type of network algorithm - was used in this study, and is considered to be an analysis of a complex Hessian matrix (Yonaba et al., 2010; Gümüş et al., 2013; Nacar et al., 2017; Okkan et al., 2018; Tayyab et al., 2019; Asadi et al. 2019; Vidyarthi et al., 2020). These algorithms were created using the Matlab program for ANN modeling, and three different transfer functions: Logsig, Tansig and Purelin (linear) were used to obtain the optimum network structure. Outputs are determined in the range of $(0,1)$ and the output is evaluated as a linear function.

The normalization process was employed on the input data. The purpose of this normalization was to homogenize the distribution of values within the data set (Okkan et al., 2018; Ilaboya and Igbinedion, 2019). Further, very large and small values - even erroneously entered values - in this set can be adapted and created on the same scale.

Mean Absolute Relative Error (MARE) and correlation coefficient $\left(\mathrm{R}^{2}\right)$ values were used as criteria for examining the model performances. The fact that the MARE value was close to the

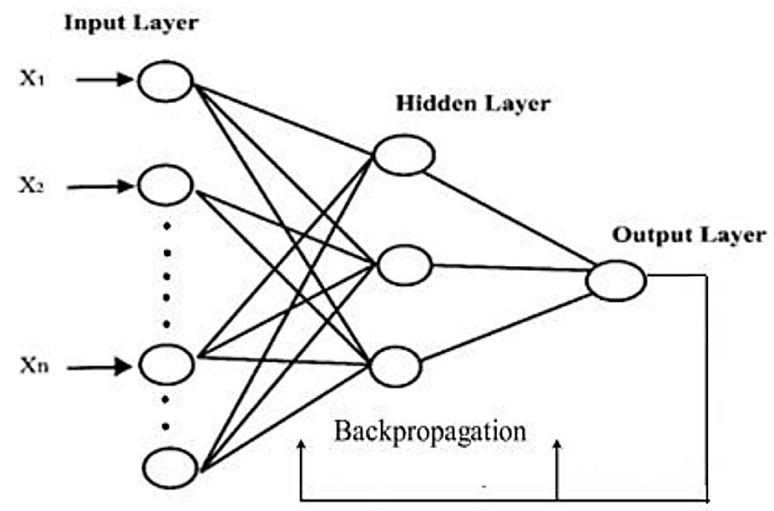

Fig. 4. General schematic structure of FFBPNN value of " 0 " and the $\mathrm{R}^{2}$ value was close to " 1 " means a good prediction model was created (Riad et al., 2004; Aichouri et al. 2015; Oral et al., 2018; Song et al., 2020). The models were also tested on different hidden layer values. The output value was taken to be "1". It can be defined The MARE formula can be defined as Eq. 1 and $\mathrm{R}^{2}$ formula can be defined as Eq. 2 .

In Eq. 2, $Q_{\text {measured }}$ shows the observed streamflow data, $\mathrm{Q}_{\text {calculated }}$ shows the flow data obtained as a result of the calculated modeling and " $\mathrm{N}$ " shows the total data (Riad et al., 2004; Aichouri et al. 2015; Yaseen et al., 2016; Oral et al. 2018; Song et al., 2020):

MARE $=\frac{1}{N} \sum_{i=1}^{N}\left|\frac{Y_{i} \text { observed }-Y_{i} \text { calculated }}{Y_{\text {iobserved }}}\right| x 100$

$$
R^{2}=\frac{\sum_{i=1}^{N}\left(Q_{\text {measured }}-Q_{\text {average }}\right)^{2}-\sum_{i=1}^{N}\left(Q_{\text {measured }}-Q_{\text {calculated }}\right)^{2}}{\sum_{i=1}^{N}\left(Q_{\text {measured }}-Q_{\text {average }}\right)^{2}}
$$

\section{Multiple Linear Regression (MLR)}

The purpose of multiple linear regression is to predict the value of the dependent variable using independent variables and to find its relationship with the independent variables (Ramana, 2014; Shoaib et al., 2018). When the dependent variable " $y$ " is represented by the arguments $x_{1}, x_{2}, . ., x_{r ;}$ the relationship between them can be shown in Eq.3 as given below (Okkan and Mollamahmutoğlu, 2010; Patel et al., 2016; Modaresi et al., 2018):

$\mathrm{y}=\beta_{0}+\beta_{1} x_{1}+\cdots+\beta_{k} x_{k}+\cdots+\beta_{r} x_{r}+\varepsilon$

where, the unknowns $\beta_{0}, \beta_{1}, \beta_{2}, \ldots, \beta_{\mathrm{k}} \ldots$, $\beta_{\mathrm{r}}$ are called as regression coefficients. Any $\beta_{\mathrm{k}}$ 
regression coefficient gives the expected amount of change in the value for " $y$ " for one unit of change in $x_{k}$ when other variables are not affected. Therefore, $\beta_{\mathrm{k}}(\mathrm{k}=1,2, \ldots, \mathrm{r})$ parameters are generally expressed as partial regression coefficients. The term $\beta_{\mathrm{o}}$ is a constant value and represents the value of the dependent variable when all $\mathrm{x}_{\mathrm{k}}$ variables are zero. The term $\varepsilon$ indicates the error term (Gümüş and Kavşut, 2013; Üneş et al., 2019; Song et al., 2020). MLR results were obtained using the Matlab program as in the ANN methods.

If there are deficiencies for observed data in a meteorological station, the data of nearby stations can be used to complete these deficiencies (Bayazit, 2003; Turhan, 2012). For the estimation of missing data, the unknown rainfall level at the station with the annual average rainfall data can be calculated with Eq. 4. In the Eq. 4, the annual average rainfall in the nearest three stations can be expressed as $\mathrm{N}_{\mathrm{A}}, \mathrm{N}_{\mathrm{B}}, \mathrm{N}_{\mathrm{C}}$, the values corresponding to the missing rainfall can be expressed as $\mathrm{P}_{\mathrm{A}}$, $\mathrm{P}_{\mathrm{B}}, \mathrm{P}_{\mathrm{C}}$, and the unknown level at the station with the annual average rainfall data can be expressed as $\mathrm{N}_{\mathrm{x}}$ (Turhan, 2012):

$$
P_{x}=\frac{1}{3}\left(\frac{N_{x}}{N_{A}} P_{A}+\frac{N_{x}}{N_{B}} P_{B}+\frac{N_{x}}{N_{C}} P_{C}\right)
$$

Missing data from Karaisalı and Çatalan ROSs were completed by using by the Eq. 4 and made suitable for modeling. Thus, different ANN architectural structures were formed with several combinations using obtained rainfall and streamflow values. Of the available data, $60 \%$ was evaluated at the training stage and $40 \%$ at the testing stage. In other words, the first $60 \%$ of the data set was trained as a block and the following part was tested. These values can be evaluated at varied rates depending on the scope of the studies (Nacar et al., 2017; Akçakoca and Apaydın, 2020).

\section{RESULTS AND DISCUSSIONS}

Rainfall-runoff model was created with different combinations using monthly average flow values from FOSs no. 1820 and 1828 at $\mathrm{t}, \mathrm{t}-1$ and $\mathrm{t}+1$, and from the monthly average rainfall values from Karaisalı and Çatalan ROSs no. 17936 and 17351 at, $t-1$ and $t+1$. Flow chart of the developed ANN model can be seen in Fig. 6.

The " $\mathrm{t}$ " time interval was chosen to run from 1992 to 2011 by scaling rainfall data between 0.10 and 0.90 . Out of a total of 236 data, 142 were evaluated at the training stage and 94 were evaluated at the testing stage. The evaluated data during

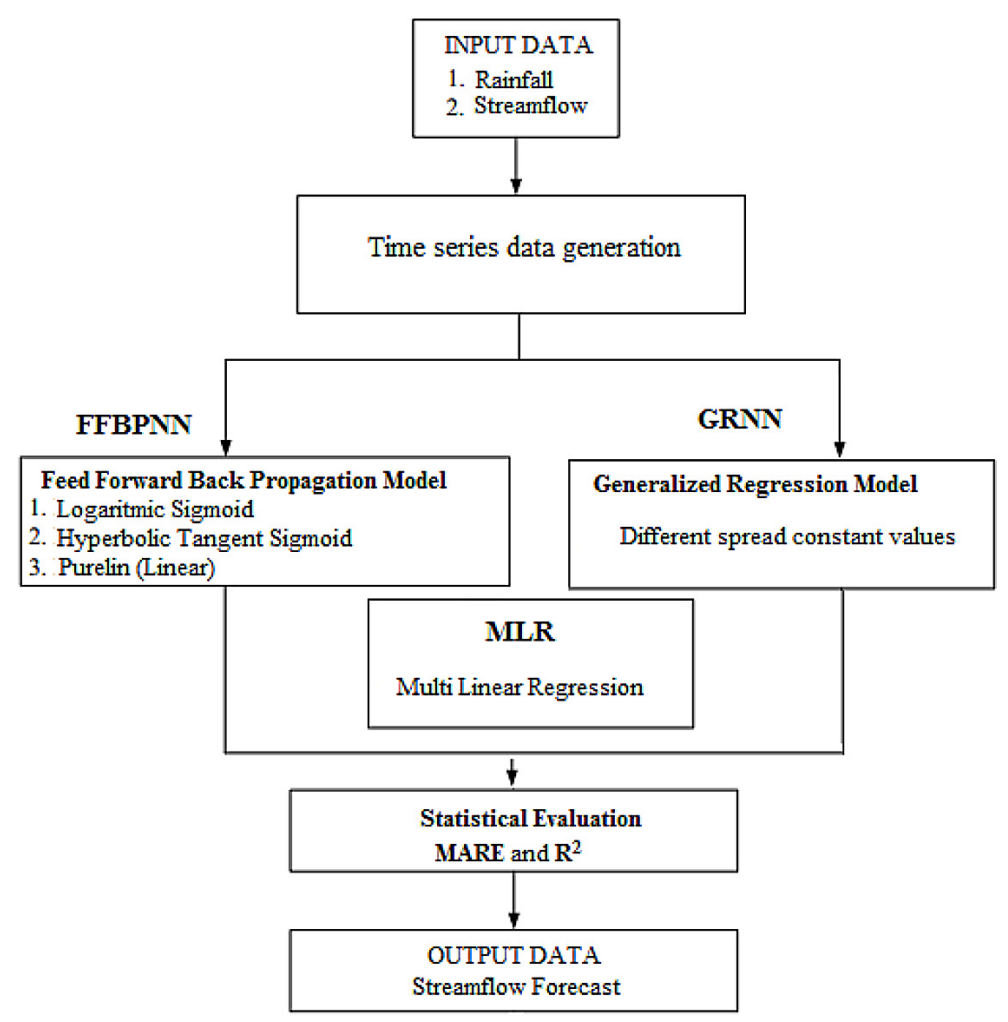

Fig. 6. Flow chart of the developed ANN model 
the testing phase were not used in the training. In order to show the relationship between ROSs and FOSs, the whole input and output data with the model numbers are shown in Table 2. In order to show the convergence amount of the FFBPNN and GRNN methods to the MLR method, the models were employed and the obtained results were presented.

Prediction results were compared according to the MARE and $\mathrm{R}^{2}$ criteria. It is thought that the closer MARE value is to " 0 " and the $\mathrm{R}^{2}$ value to " 1 ", the more accurate convergence is achieved to the predicted value. In general, it was observed that ANN methods provided a very high approximation to the MLR method, and some models yielded slightly better results. It was observed in the models that the ANN architectural structure giving the best results had " 5 " input data, and obtained optimum results when the hidden layer value was the value of "1" (Fig. 7).

The best results obtained for training and testing stages for FFBPNN, GRNN, and MLR models can be seen in Table 3. The obtained $\mathrm{R}^{2}$ values

Table 2. ANN and MLR model inputs and outputs

\begin{tabular}{|c|c|c|}
\hline $\begin{array}{c}\text { Model } \\
\text { No }\end{array}$ & Input & Output \\
\hline 1 & $P_{1}(t), P_{2}(t), Q_{1}(t) Q_{1}(t+1), Q_{2}(t+1)$ & $Q_{2}(t)$ \\
\hline 2 & $P_{1}(t), P_{2}(t), Q_{2}(t) Q_{2}(t+1), Q_{1}(t+1)$ & $Q_{1}(t)$ \\
\hline 3 & $P_{1}(t), P_{1}(t+1), Q_{1}(t), Q_{1}(t+1), Q_{2}(t+1)$ & $Q_{2}(t)$ \\
\hline 4 & $P_{2}(t), P_{2}(t+1), Q_{1}(t), Q_{1}(t+1), Q_{2}(t+1)$ & $Q_{2}(t)$ \\
\hline 5 & $P_{1}(t), P_{1}(t+1), Q_{2}(t), Q_{2}(t+1), Q_{1}(t+1)$ & $Q_{1}(t)$ \\
\hline 6 & $P_{2}(t), P_{2}(t+1), Q_{2}(t), Q_{2}(t+1), Q_{1}(t+1)$ & $Q_{1}(t)$ \\
\hline 7 & $P_{1}(t), P_{2}(t), Q_{1}(t) Q_{1}(t-1), Q_{2}(t-1)$ & $Q_{2}(t)$ \\
\hline 8 & $P_{1}(t), P_{2}(t), Q_{2}(t), Q_{2}(t-1), Q_{1}(t-1)$ & $Q_{1}(t)$ \\
\hline 9 & $P_{1}(t), P_{1}(t-1), Q_{1}(t), Q_{1}(t-1), Q_{2}(t-1)$ & $Q_{2}(t)$ \\
\hline 10 & $P_{2}(t), P_{2}(t-1), Q_{1}(t), Q_{1}(t-1), Q_{2}(t-1)$ & $Q_{2}(t)$ \\
\hline 11 & $P_{1}(t), P_{1}(t-1), Q_{2}(t), Q_{2}(t-1), Q_{1}(t-1)$ & $Q_{1}(t)$ \\
\hline 12 & $P_{2}(t), P_{2}(t-1), Q_{2}(t), Q_{2}(t-1), Q_{1}(t-1)$ & $Q_{1}(t)$ \\
\hline
\end{tabular}

indicated compatibility with the observed data. A value between $85 \%$ and $100 \%$ means that the model is suitable in terms of performance value.

Since the MARE indicates average error value, a value closer to zero indicates that the error rate is reduced (Sattari et al., 2012; Yaseen et al., 2016; Vidyarthi et al., 2020; Song et al., 2020). In the Table 3, it is noteworthy that the FFBPNN method in particular creates very similar data to those of the MLR results. Although the MARE values are close to each other in all methods, it was observed that there was a decrease in some models. Notwithstanding the MLR yielded better results, even if only a little, it was seen that the FFBPNN in particular generally provided a better approach among the whole ANN methods. This result is consistent with the previous studies in literature (Gümüş and Kavşut, 2013; Gümüş et al., 2013; Tayyab et al., 2016; Turhan et al., 2016a). Considering basin-based studies, many researchers have found that ANN methods yielded satisfactory results (Sun et al., 2019; Obasi et al., 2020).

In order to test the sensitivity of the models, simulations with three transfer functions (Logsig, Tansig, and Purelin) were employed. The obtained results are shown in Table 4.

In the Table 4, it can be emphasized that results for the three different transfer functions were found similar. It can be concluded that the data are very close to the MLR method, which is a conventional method and widely accepted. Furthermore, to test the consistency of the GRNN and FFBPNN methods, the effect of the hidden neuron and spread number variations for Model-9 was investigated. The related graphs can be seen in Fig. 8.

When the graphs are examined, the spread value tends to increase with a few exceptions.

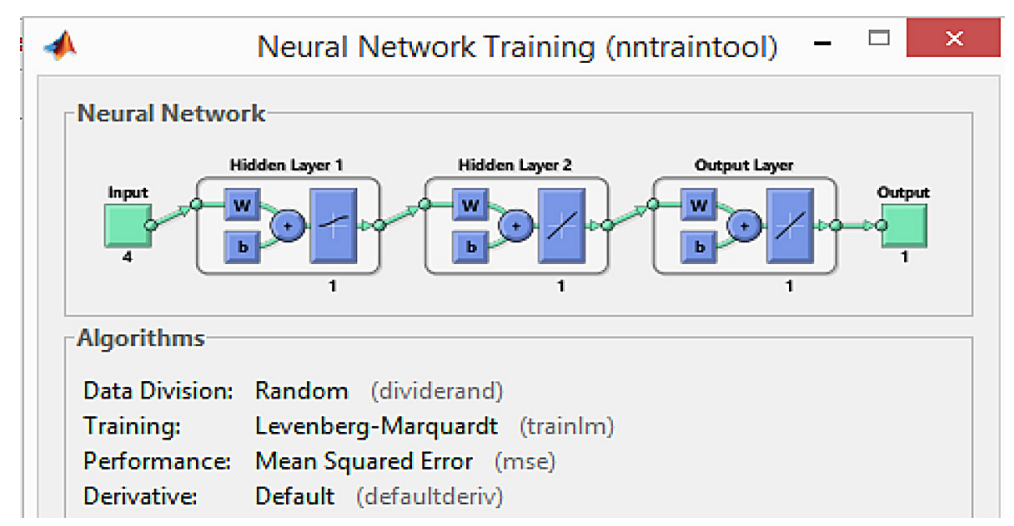

Fig. 7. The most suitable ANN architecture $(5,1,1)$ 
Table 3. Training and testing results for FFBPNN, GRNN and MLR modeling

\begin{tabular}{|c|c|c|c|c|c|}
\hline \multirow{2}{*}{ Name } & \multirow{2}{*}{ Method } & \multicolumn{2}{|c|}{ Training } & \multicolumn{2}{|c|}{ Testing } \\
\cline { 3 - 6 } & & $\mathrm{R}^{2}$ & MARE & $\mathrm{R}^{2}$ & MARE \\
\hline \multirow{4}{*}{ Model-1 } & FFBNN & 89.26 & 36.74 & 81.86 & 30.23 \\
\cline { 2 - 6 } & GRNN & 96.63 & 26.96 & 73.67 & 55.07 \\
\cline { 2 - 6 } Model-6 & MLR & 87.86 & 32.94 & 83.30 & 61.80 \\
\hline \multirow{4}{*}{ Model-7 } & FFBNN & 91.43 & 26.09 & 82.67 & 52.78 \\
\cline { 2 - 6 } & GRNN & 95.69 & 25.72 & 73.43 & 70.74 \\
\cline { 2 - 6 } & MLR & 88.96 & 25.30 & 82.28 & 38.91 \\
\hline & FFBNN & 87.76 & 31.63 & 82.87 & 22.07 \\
\cline { 2 - 6 } Model-8 & 94.92 & 36.80 & 78.93 & 60.43 \\
\hline & MLR & 88.25 & 33.00 & 83.10 & 54.88 \\
\cline { 2 - 6 } & GRNN & 90.32 & 25.89 & 81.91 & 42.88 \\
\cline { 2 - 6 } Model-9 & MLR & 88.32 & 27.27 & 77.06 & 71.57 \\
\hline & FFBNN & 87.60 & 33.14 & 82.99 & 22.84 \\
\cline { 2 - 6 } & GRNN & 94.17 & 40.77 & 79.22 & 61.94 \\
\cline { 2 - 6 } & MLR & 88.10 & 35.34 & 83.50 & 56.49 \\
\hline
\end{tabular}

It is possible to state that there are decrements for the spread value. There is usually a logarithmic and exponential increase in Spread-MARE graph. In terms of training and testing phases for the Model-9 - which gave the best results - timedependent flow trends and flow estimation graphs obtained with the FFBPNN, GRNN and MLR methods can be seen in Fig. 9.

It was seen that the two ANN methods created very similar results compared to the MLR. Furthermore, it was seen that the observed and calculated values are quite close to each other, except for the peak values of the streamflows.

The most suitable relationship network with regard to $\mathrm{R}^{2}$ and MARE values were obtained with the FFBPNN in Model-9 for ROS no 17936, FOS nos 1820 and 1828, and also it was consistent with the results of other methods. Even
Table 4. Using different transfer functions in the FFBPNN models

\begin{tabular}{|c|c|c|c|c|c|}
\hline \multirow{2}{*}{ Name } & \multirow{2}{*}{ FFBPNN } & \multicolumn{2}{|c|}{ Training } & \multicolumn{2}{|c|}{ Testing } \\
\cline { 3 - 6 } & & $\mathrm{R}^{2}$ & MARE & $\mathrm{R}^{2}$ & MARE \\
\hline \multirow{4}{*}{ Model-1 } & Logsig & 89.26 & 36.74 & 81.86 & 30.23 \\
\cline { 2 - 6 } & Tansig & 88.93 & 35.54 & 82.21 & 26.53 \\
\cline { 2 - 6 } Model-6 & Purelin & 89.40 & 41.43 & 81.71 & 41.33 \\
\hline & Logsig & 91.43 & 26.09 & 82.67 & 52.78 \\
\cline { 2 - 6 } & Tansig & 91.37 & 26.92 & 82.56 & 57.07 \\
\cline { 2 - 6 } Model-7 & Purelin & 91.43 & 25.26 & 82.66 & 50.28 \\
\hline & Logsig & 87.76 & 31.63 & 82.87 & 22.07 \\
\cline { 2 - 6 } & Tansig & 87.76 & 31.54 & 82.83 & 22.34 \\
\cline { 2 - 6 } Model-8 & Purelin & 87.75 & 31.63 & 82.86 & 22.04 \\
\cline { 2 - 6 } & Logsig & 90.32 & 25.89 & 81.91 & 42.88 \\
\cline { 2 - 6 } & Tansig & 90.31 & 24.62 & 80.73 & 41.89 \\
\hline \multirow{3}{*}{ Model-9 } & Purelin & 90.32 & 25.88 & 81.89 & 42.81 \\
\cline { 2 - 6 } & Logsig & 87.60 & 33.14 & 82.99 & 22.84 \\
\cline { 2 - 6 } & Tansig & 86.61 & 35.70 & 82.53 & 24.58 \\
\cline { 2 - 6 } & Purelin & 87.56 & 33.94 & 83.08 & 23.30 \\
\hline
\end{tabular}

though the GRNN accomplished a very high $\mathrm{R}^{2}$ value during the training phase, it achieved less convergence in the testing compared to other methods. The Logsig, which has a lower error rate as a transfer function, put out optimal values.

In the GRNN models, the spread value of 0.03 yielded the lowest error rate. In the models performed on the number of hidden neurons, it was observed that the value of " 1 " produced the highest $\mathrm{R}^{2}$ value and the lowest error rate. It was observed that the error rates increase at the turning points of the curves; however, the results of the FFBPNN were closer to the $\mathrm{y}=\mathrm{x}$ (exact) line, and the obtained results by the MLR were condensed around certain points, according to the GRNN. This may be caused due to the MARE values being further away from the value of zero for the GRNN results. Although the $\mathrm{R}^{2}$ value is high, the
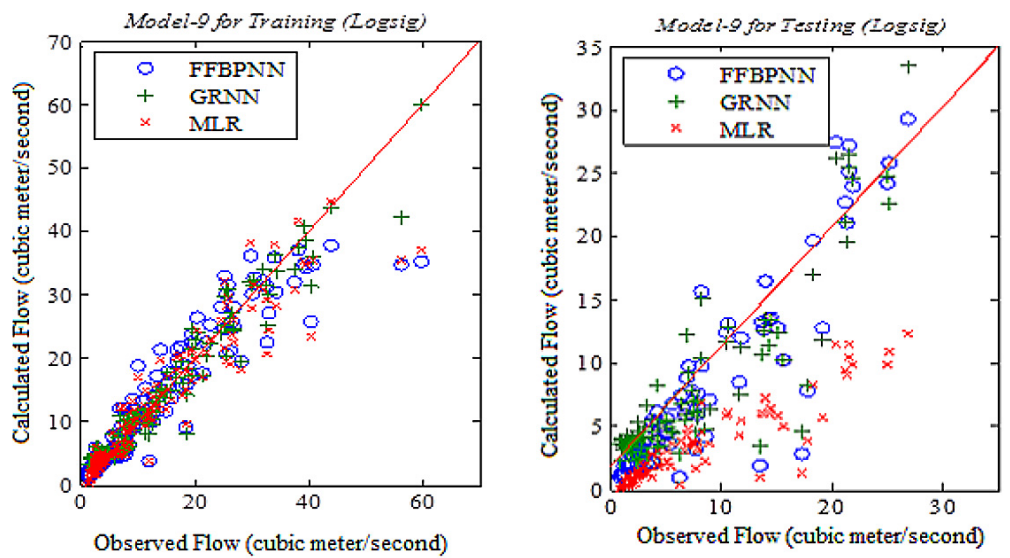

Fig. 8. Graphs of the changes in Spread-MARE and $\mathrm{R}^{2}-\mathrm{MARE}-\mathrm{k}$ values 
reason for moving away from the symmetry axis can be explained by the increase in the error rate, namely, the MARE values. Scatter plots of the calculated and observed flow data of Model-9 for training and testing, are shown in Figure 10.

\section{CONCLUSIONS}

In the present study, the relationship between monthly average streamflow data from FOS nos 1820 and 1828 and monthly total precipitation or rainfall data from ROS nos 17351 and 17936 was investigated using the FFBPNN and GRNN for one of the irrigation dams in the Seyhan subbasin. The obtained results were compared to the MLR method. Of the actual data, $60 \%$ was tried during the training process, while the remaining $40 \%$ was performed only in the testing phase. After many modeling processes, to investigate the best approach, rainfall and streamflow values were considered as inputs and the flow value was estimated according to these ANN architectures.

Therefore, in order to evaluate their performances, three different transfer functions: Logarithmic Sigmoid (Logsig), Hyperbolic Tangent Sigmoid (Tansig) and Purelin (Linear) were used in modeling these network structures to evaluate
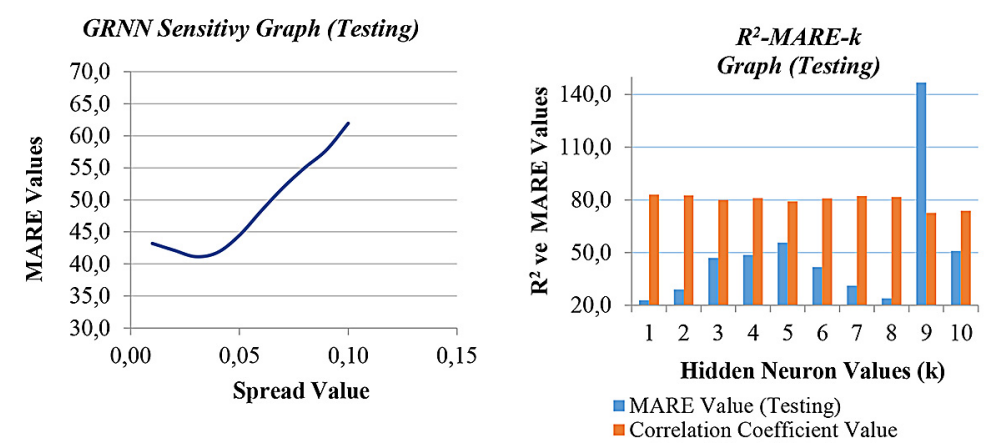

Fig. 9. ANN Model-9 Scattering plots for training and testing phases
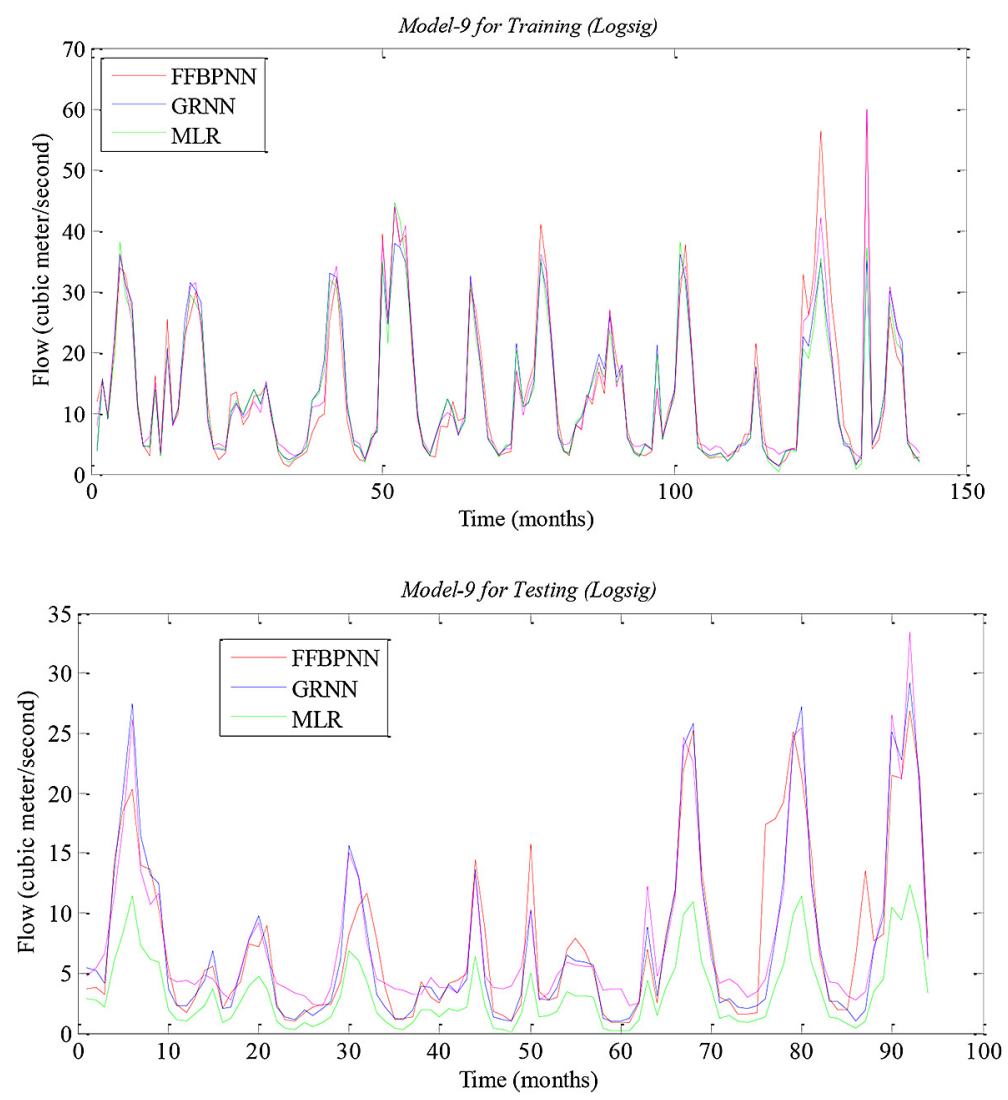

Fig. 10. Scatter plots of the calculated and observed flow data for training and testing of Model-9 
their performances. To test the sensitivity of the FFBPNN and GRNN methods, the effect of hidden neurons and variations in spread value were also researched. Consequently, it was regarded that $(5,1,1)$ is the most suitable ANN architecture for this study.

It can be concluded that streamflow estimation models, analyzed with the ANN, can successfully model the non-linear rainfall-runoff relationship of river basins. With the aim of investigating the relationship, it is thought that using the FFBPNN method can be a good alternative as a result of the application of the ANN methods methods for the Nergizlik Dam area. It is a fact that the autocorrelation function effect on the streamflow estimation can be increased with using more hydrological data values and in this way the performance of the models can be further improved. The results already present a high correlation and minimum error rates. Thus, it was concluded that the ANN input data for this study was required and sufficient to model the Nergizlik Dam inflows. It is also obvious that ANN methods will provide significant advantages, especially in supporting decision-making processes, when it was needed to plan and manage appropriately and sustainably of water resources.

\section{REFERENCES}

1. Adnan RM, Liang Z, Heddam S, Zounemat-Kermani M, Kişi Ö, Li B (2020) Least square support vector machine and multivariate adaptive regression splines for streamflow prediction in mountainous basin using hydrometeorological data as inputs. Journal of Hydrology 586:124371. https://doi. org/10.1016/j.jhydrol.2019.124371

2. Aichouri I, Hani A, Buogherira N, Djabri L, Chaffai H, Lallahem S (2015) River flow model using artificial neural networks. Energy Procedia 74:1007-1014

3. Akçakoca F, Apaydın H (2020) Modelling of Bektas Creek daily streamflow with generalized regression neural network method. International Journal of Advances in Scientific Research and Engineering (ijasre) 6(2):97-103. DOI: 10.31695/ IJASRE.2020.33717

4. Aktürk G, Yıldız O (2015) A drought analysis of Sivas using the standardized precipitation index (Spi) method and drought estimation with the artificial neural networks. International Journal of Advances in Mechanical and Civil Engineering 2(5):24-30

5. Aktürk G, Yıldız O (2018) The effect of precipitation deficits on hydrological systems in the Çatalan Dam Basin, Turkey. International Journal of Engineering Research and Development 10(2):10-28. https:// doi.org/10.29137/umagd.441389

6. Ali S, Shahbaz M (2020) Streamflow forecasting by modeling the rainfall-streamflow relationship using artificial neural networks. Modeling Earth Systems and Environment 6: 1645-1656. https:// doi.org/10.1007/s40808-020-00780-3

7. Alp M, Ciğgizoğlu HK (2004) Modelling rainfallrunoff relation using different artificial neural network methods. İtü Dergisi/d Mühendislik (in Turkish) 3(1):80-88

8. Asadi H, Shahedi K, Jarihani B, Sidle RC (2019) Rainfall-runoff modelling using hydrological connectivity index and artificial neural network approach. Water MDPI 11:212. doi:10.3390/ w11020212

9. Ateeq-ur-Rauf, Ghumman AR, Ahmad S, Hashmi HN (2018) Performance assessment of artificial neural networks and support vector regression models for stream flow predictions. Environ Monit Assess 190:704. https://doi.org/10.1007/ s10661-018-7012-9

10. Bakış R, Göncü S (2015) Completion of missing data in rivers flow measurement: Case study of $\mathrm{Zab}$ River Basin. Anadolu University Journal of Science and Technology A-Applied Sciences and Engineering 16(1):63-79. DOI: 10.18038/btd-a.45640

11. Bayazit M (2003) Hydrology. Birsen Press, Istanbul, Turkey (in Turkish)

12. Besaw LE, Rizzo DM, Bierman PR, Hackett WR (2010) Advances in ungauged streamflow prediction using artificial neural networks. Journal of Hydrology 386:27-37. doi:10.1016/j.jhydrol.2010.02.037

13. Bisoyi N, Gupta H, Padhy NP, Chakrapani GJ (2018) Prediction of daily sediment discharge using a backpropagation neural network training algorithm: A case study of the Narmada River, India. International Journal of Sediment Research 34(2):125-135. https://doi.org/10.1016/j.ijsrc.2018.10.010

14. Boucher MA, Quilty J, Adamowski J (2020) Data assimilation for streamflow forecasting using extreme learning machines and multilayer perceptrons. Water Resources Research 56(6):31. https:// doi.org/10.1029/2019WR026226

15. Daliakopoulos IN, Tsanis IK (2016) Comparison of an artificial neural network and a conceptual rainfall-runoff model in the simulation of ephemeral streamflow. Hydrological Sciences Journal 61(15):2763-2774. http://dx.doi.org/10.1080/0262 6667.2016.1154151

16. Dorum A, Yarar A, Sevimli MF, Onüçyıldız M (2010) Modelling the rainfall-runoff data of susurluk basin. Expert Systems with Applications 37:6587-6593 
17. Drisya J, Kumar DS, Roshni T (2020) Hydrological drought assessment through streamflow forecasting using wavelet enabled artificial neural networks. Environment, Development and Sustainability. https://doi.org/10.1007/s10668-020-00737-7

18. Eyüpoğlu V, Eren B, Doğan E (2010) Prediction of ionic $\mathrm{Cr}$ (VI) extraction efficiency in flat sheet supported liquid membrane using artificial neural networks (ANNs). Int. J. Environ. Res. 4(3):463-470

19. Electrical Work Surveying Administration (EWSA) (2008) Water flows annual book. Ankara, Turkey

20. Farajzadeh J, Fard AF, Lotfi S (2014) Modeling of monthly rainfall and runoff of Urmia lake basin using "feed-forward neural network" and " time series analysis" model. Water Resources and Industry 7(8):38-48. http://dx.doi.org/10.1016/j. wri.2014.10.003

21. Ghumman AR, Ghazaw YM, Sohail AR, Watanabe K (2011) Runoff forecasting by artificial neural network and conventional model. Alexandria Engineering Journal 50:345-350. doi:10.1016/j. aej.2012.01.005

22. Gümüş V, Kavşut E (2013) Zamanti NehriErgenuşağı İstasyonu eksik aylık akım verilerinin tahmini (in Turkish). GU J Sci Part:C 1(2):81-91

23. Gümüş V, Soydan NG, Şimşek O, Aköz MS, Kurkgöz MS (2013) Comparison of different artificial neural networks for rainfall-runoff modeling. Çukurova University Journal of the Faculty of Engineering and Architecture 28(1):37-49

24. Gümüş V, Başak A, Yenigün K (2018) Drought estimation of Şanliurfa Station with artificial neural network. GU J Sci, Part C 6(3): 621-633. DOI: 10.29109/gujsc. 393154

25. Gümüş V (2019) Spatio-temporal precipitation and temperature trend analysis of the Seyhan-Ceyhan River Basins, Turkey. Meteorol Appl. 26:369-384. DOI: $10.1002 /$ met. 1768

26. Hosseini SM, Majhouri N (2016) Integrating support vector regression and a geomorphologic artificial neural network for daily rainfall-runoff modeling. Applied Soft Computing 38:329-345. https:// doi.org/10.1016/j.asoc.2015.09.049

27. Huo Z, Feng S, Kang S, Huang G, Wang F, Guo P (2012) Integrated neural networks for monthly river flow estimation in arid inland basin of Northwest China. doi:10.1016/j.jhydrol.2011.11.054

28. Ilaboya IR, Igbinedion OE (2019) Performance of multiple linear regression (MLR) and artificial neural network (ANN) for the prediction of monthly maximum rainfall in Benin City, Nigeria. International Journal of Engineering Science and Application 3(1):21-37

29. Kişi Ö (2008) River flow forecasting and estimation using different artificial neural network techniques.
Hydrology Research 39(1):27-40. doi: 10.2166/ nh.2008.026

30. Komasi M, Sharghi S (2016) Hybrid wavelet-support vector machine approach for modelling rainfall-runoff process. Water Science and Technology 73(8):1937-1953. doi: 10.2166/wst.2016.048

31. Kumar S, Roshni T, Himayoun D (2019) A comparison of emotional neural network (ENN) and artificial neural network (ANN) approach for rainfall-runoff modelling. Civil Engineering Journal 5(10):2120-2130. http://dx.doi.org/10.28991/ cej-2019-03091398

32. LV Z, Zuo J, Rodriguez D (2020) Predicting of runoff using an optimized SWAT-ANN: A case study. Journal of Hydrology: Regional Studies 29:100688. https://doi.org/10.1016/j.ejrh.2020.100688

33. Meng X, Yin M, Ning L, Liu D, Xue X (2015) A threshold artificial neural network model for improving runoff prediction in a karst watershed. Environ Earth Sci 74:5039-5048. DOI 10.1007/ s12665-015-4562-9

34. Mishra PK, Karmakar S (2018) Performance of optimum neural network in rainfall-runoff modeling over a river basin. International Journal of Environmental Science and Technology 16:1289-1302. https://doi.org/10.1007/s13762-018-1726-7

35. Modaresi F, Araghinejad S, Ebrahimi K (2018) A comparative assessment of artificial neural network, generalized regression neural network, least-square support vector regression, and K-Nearest neighbor regression for monthly streamflow forecasting in linear and nonlinear conditions. Water Resources Management 32(1):243-258. DOI: $10.1007 /$ s11269-017-1807-2

36. Nacar S, Hinıs MA, Kankal M (2017) Forecasting daily streamflow discharges using various neural network models and training algorithms. KSCE Journal of Civil Engineering 22:3676-3685. https:// doi.org/10.1007/s12205-017-1933-7

37. Nawaz N, Harun S, Othman R, Heryansyah A (2015) Rainfall runoff modeling by multilayer perceptron neural network for Lui River catchment. Jurnal Teknologi 78:6-12

38. Nourani V, Khanghah TR, Baghanam AH (2015) Application of entropy concept for input selection of wavelet-ANN based rainfall-runoff modeling. Journal of Environmental Informatics 26(1):52-70. doi:10.3808/jei.201500309

39. Obasi AA, Ogbu KN, Oracwe LC, Ahaneku IE (2020) Rainfall-river discharge modelling for flood forecasting using Artificial Neural Network (ANN). Journal of Water and Land Development 44(I-III):98-105. https://DOI.org/10.24425/jwld.2019.127050

40. Okkan U, Mollamahmutoğlu A (2010) Daily runoff modelling of Yiğitler Stream by using artificial neural 
networks and regression analysis. Dumlupınar Üniversitesi Fen Bilimleri Enstitüsü Dergisi (in Turkish)- Journal of Scientific Reports-A 23:33-48

41. Okkan U, Dalkılıç HY (2012) Monthly runoff model for Kemer Dam with radial based artificial neural networks. IMO Teknik Dergi (in Turkish) 379:5957-5966

42. Okkan U, Serbeş ZA, Gedik N (2018) MATLAB ile Levenberg-Marquardt algoritması tabanlı YSA uygulaması: Aylık yağış-akış modellemesi (in Turkish). Dicle Üniversitesi Mühendislik Fakültesi Mühendislik Dergisi 9(1):351-362

43. Oral M, Kartal S, Özyıldırım BM (2018) A cluster based approach to reduce pattern layer size for generalized regression neural network. Pamukkale University Journal of Engineering Sciences 24(5):857-863. doi: 10.5505/pajes.2017.76401

44. Özfidaner M, Şapolyo D, Topaloğlu F (2018) Seyhan havzası akım verilerinin hidrolojik kuraklık analizi. Soil Water Journal 7(1):57-64. DOI : 10.21657/topraksu.410140

45. Panagoulia D, Tsekouras GJ, Kousiouris G (2017) A multi-stage methodology for selecting input variables in ANN forecasting of river flows. Global Nest Journal 19(1):49-57

46. Patel AB, Joshi GS (2017) Modeling of rainfallrunoff correlations using artificial neural network-A case study of Dharoi Watershed of a Sabarmati River Basin, India. Civil Engineering Journal 3(2):78-87

47. Patel S, Hardaha MK, Seetpal M, Madankar KK (2016) Multiple linear regression model for stream flow estimation of Wainganga River. American Journal of Water Science and Engineering 2(1):1-5. doi: 10.11648/j.ajwse.20160201.11

48. Ramana GV (2014) Regression analysis of rainfall and runoff process of a typical watershed. International Journal of Science and Applied Information Technology 3(1):16-26

49. Riad S, Mania J (2004) Rainfall-Runoff model using an artificial neural network approach. Mathematical and Computer Modelling 40:839-846

50. Sahoo A, Samantaray S, Ghose DK (2019) Stream flow forecasting in Mahanadi River Basin using artificial neural networks. Procedia Computer Science 157:168-174. 10.1016/j.procs.2019.08.154

51. Sattari MT, Fakher-Fard A, Docherkhesaz M, Öztürk F (2007) Simulation of Savalan Irrigation Reservoir by using artificial neural networks. Journal of Agricultural Sciences-Ankara University Faculty of Agriculture 13(4):337-345

52. Sattari MT, Yürekli K, Ünlükara A (2011) Drought prediction by using artificial neural networks approach in Karaman Province. Journal of Agricultural Sciences-Ankara University Faculty of Agriculture 4(1):7-13
53. Sattari MT, Yürekli K, Pal M (2012) Performance evaluation of artificial neural network approaches in forecasting reservoir inflow. Applied Mathematical Modelling 36:2649-2657. doi:10.1016/j. apm.2011.09.048

54. Seçkin N, Çobaner M, Yurtal R, Haktanır T (2013) Comparison of artificial neural network methods with L-moments for estimating flood flow at ungauged sites: the case of East Mediterranean River Basin, Turkey. Water Resources Management 27:2103-2124. https://doi.org/10.1007/ s11269-013-0278-3

55. Selek B, Önöz B, Yılmaz MU, Aksu H, Öztürk AF, Sarıkaya, MS, Sezer S (2019) Monthly streamflow estimation model Murat River Basin application. Presented at the 9th International Symposium on Atmospheric Sciences, Istanbul.

56. Shoaib M, Shamseldin AY, Khan S, Khan MM, Khan ZM,Sultan T, Melville BW (2018) A comparative study of various hybrid wavelet feed forward neural network models for runoff forecasting. Water Resources Management 32:83-103. DOI 10.1007/ s11269-017-1796-1

57. Singh A, Malik A., Kumar A., Kişi Ö (2018) Rainfall-runoff modeling in hilly watershed using heuristic approaches with gamma test. Arabian Journal of Geosciences 11:261. https://doi.org/10.1007/ s12517-018-3614-3

58. Song P, Liu W, Sun J, Wang C, Kong L, Nong Z, Lei X, Wang H (2020) Annual runoff forecasting based on multi-model information fusion and residual error correction in the Ganjiang River Basin. Water MDPI 12:2086. doi:10.3390/w12082086

59. Sönmez O, Çeribaşı G, Doğan E (2016) Short and long term streamflow prediction by different neural network approaches and trend analysis methods: Case study of Sakarya River, Turkey. Fresenius Environmental Bulletin 25(2):565-579

60. Sun Y, Niu J, Sivakumar B (2019) A comparative study of models for short-term streamflow forecasting with emphasis on wavelet-based approach. Stochastic Environmental Research and Risk Assessment 33:1875-1891. https://doi.org/10.1007/ s00477-019-01734-7

61. Tayfur G, Aksoy H, Eriş E (2018) Prediction of rainfall runoff-induced sediment load from bare land surfaces by generalized regression neural network and empirical model. Water and Environment Journal 34(1):66-76. doi:10.1111/wej.12442

62. Tayyab M, Zhou J, Zeng X, Adnan R (2016) Discharge forecasting by applying artificial neural networks at The Jinsha River Basin, China. European Scientific Journal 12(9):108-127

63. Tayyab M, Zhou J, Dong X, Ahmad I, Sun N (2019) Rainfall-runoff modeling at Jinsha River basin by integrated neural network with discrete wavelet 
transform. Meteorol Atmos Phys 131:115-125. https://doi.org/10.1007/s00703-017-0546-5

64. Turhan E (2012) Modelling of rainfall-runoff relation with artificial neural network methods for Seyhan Basin. MSc Thesis Çukurova University Institute of Natural and Applied Sciences-Adana.

65. Turhan E, Özmen-Çağatay H (2016a) Using of artificial neural network (ANN) for setting estimation model of missing flow data: Asi River-Demirköprü Flow Observation Station (FOS). Çukurova University Journal of the Faculty of Engineering and Architecture 31(1):93-106

66. Turhan E, Özmen-Çağatay H, Çetin A (2016b) Modelling of rainfall-runoff relation with artificial neural network methods for Lower Seyhan Plain Sub-Basin and assessment in point of rainy-droughty terms. Çukurova University Journal of the Faculty of Engineering and Architecture 31(2):227-241

67. Turhan E, Kaya Keleş M, Tantekin A, Keleş AE (2019) The investigation of the applicability of data-driven techniques in hydrological modeling: The case of Seyhan Basin. Rocznik Ochrona Środowiska 21(1):29-51

68. Turkish State Hydraulic Works (DSI) (2011) Observed streamflow monthly book. Ankara, Turkey

69. Ustaoğlu B, Cığızoğlu HK, Karaca M (2008) Forecast of daily mean, maximum and minimum temperature time series by three artificial neural network methods. Meteorol. Appl. 15: 431-445. DOI: $10.1002 /$ met.83

70. Üneş F, Keskin L, Demirci M (2019) Artificial neural networks method for prediction of rainfall-runoff relation: Regional practice. Natural and Engineering
Science 4(3): 220-230

71. Vidyarthi VK, Jain A, Chourasiya S (2020) Modeling rainfall-runoff process using artificial neural network with emphasis on parameter sensitivity. Modeling Earth Systems and Environment 6(2):12. https://doi.org/10.1007/s40808-020-00833-7

72. Yaseen ZM, Allawi MF, Yousif AA, Jaafar O, Hamzah FM, El-Shaife A(2016) Non-tuned machine learning approach for hydrological time series forecasting. Neural Comput \& Applic 30:1479-1491. https://doi.org/10.1007/s00521-016-2763-0

73. Y1ldiran A, Kandemir SY (2018) Estimation of rainfall amount with artificial neural networks. Bilecik Şeyh Edebali University (BSEU) Journal of Science 5(2):97-104

74. Yin S, Tang D, Jin X, Chen W, Pu N (2016) A combined rotated general regression neural network method for river flow forecasting. Hydrological Sciences Journal 61(4):669-682. http://dx.doi.org /10.1080/02626667.2014.944525

75. Yonaba H, Anctil F, Fortin V (2010) Comparing sigmoid transfer functions for neural network multistep ahead streamflow forecasting. Journal of Hydrologic Engineering 15(4):275-283. DOI: 10.1061/ (ASCE)HE.1943-5584.0000188

76. Yüksek Ö, Babacan HT, Saka F (2018) Yağış-akış modellemesinde optimum yapay sinir ağı yapısının araştırılması (in Turkish). Turkish Journal of Hydraulic 2(1):31-37

77. Zhou J, Peng T, Zhang C, Sun N (2018) Data preanalysis and ensemble of various artificial neural networks for monthly streamflow forecasting. Water MDPI 10:628. doi:10.3390/w10050628 